Article

\title{
On the Road to a Green Economy: How Do European Union Countries 'Do Their Homework'?
}

\author{
Armand Kasztelan (ID
}

Citation: Kasztelan, A. On the Road to a Green Economy: How Do European Union Countries 'Do Their Homework'? Energies 2021, 14, 5941. https://doi.org/10.3390/en14185941

Academic Editors: Luigi Aldieri, Pablo del Río and Peter V. Schaeffer

Received: 30 July 2021

Accepted: 15 September 2021

Published: 18 September 2021

Publisher's Note: MDPI stays neutral with regard to jurisdictional claims in published maps and institutional affiliations.

Copyright: (C) 2021 by the author. Licensee MDPI, Basel, Switzerland. This article is an open access article distributed under the terms and conditions of the Creative Commons Attribution (CC BY) license (https:// creativecommons.org/licenses/by/ $4.0 /)$.
Department of Economics and Agribusiness, University of Life Sciences in Lublin, Akademicka 13, 20-950 Lublin, Poland; armand.kasztelan@up.lublin.pl

\begin{abstract}
Multidimensional crisis phenomena (financial-economic, environmental and social), plaguing the international community, especially in the last 30 years, have intensified resentment towards traditional models of growth and socio-economic development. The European Commission has placed the idea of a green economy (GE) at the heart of the Europe 2020 strategy. This paper presents an assessment of the implementation of the green economy assumptions in EU countries in 2018, taking 2010 as the base year. Using taxonomic methods, a synthetic evaluation index (GEI-Green Economy Index) was constructed based on a multi-criterion set of 27 indicators. This paper attempts to answer the following questions: How green are the European economies? What are the main challenges in this context? The average value of the index for the EU countries decreased in the studied years from 0.3423 to 0.3294 , which can be interpreted as a slowdown in the greening processes. The key recommendations for the upcoming years include the improvement of energy efficiency indicators, the further increase in the share of renewable energy sources in the energy balance. Moreover, a significant problem continues to be the high percentage of the population at risk of poverty or social exclusion, as well as low $\mathrm{CO}_{2}$ and resource productivity rates.
\end{abstract}

Keywords: green economy; sustainable development; taxonomic methods; zero unitarisation method; synthetic index; EU countries; indicators; comparative analysis; ranking

\section{Introduction}

The term 'green economy' was coined in 1989 in the report titled Blueprint for a Green Economy, written by three economists: D. Pearce, A. Markandya and E.B. Barbier. The main objective of the report was to support the British government in implementing the idea of sustainable development [1]. The contemporary process of defining and investigating green economy is associated with the year 2008 when the so-called Green Economy Initiative was brought to life under the United Nations Environmental Programme (UNEP). Its objective was to assist governments in "greening" their economies by reshaping and refocusing policies, investments and spending towards a range of sectors, such as clean technologies, renewable energies, water services, green transportation, waste management, green buildings and sustainable agriculture and forests.

After the climate conference in Copenhagen (2009), UNEP mentioned the concept of green economy as a method to approach the essential environmental, social and economic challenges and a chance for this development to benefit all countries. UNEP defined green economy as "one that results in improved human well-being and social equity, while significantly reducing environmental risks and ecological scarcities" [2].

In the Europe 2020 strategy, the European Commission presented a vision of resourceefficient and low-carbon economy and, during preparations for the RIO+20 summit in 2012, denoted the green economy as the economy which ensures growth, creating jobs and eliminating poverty through investing and protecting the natural capital which determines the survival of our planet in the long run. It is a resource-efficient and socially inclusive economy. 
The European Commission finds a green economy to be more than a sum of existing commitments. It has the potential for introducing us to a new development paradigm and a new business model in which growth, development and the natural environment are deemed mutually supportive. Increasing resource efficiency, promoting sustainable consumption and production, preventing climate change, protecting biodiversity, combating desertification, reducing pollution, and managing natural resources and ecosystems in a responsible manner are necessities and a simultaneous driving force ensuring the transition to a green economy [3,4]. The main purpose of the study was the evaluation of green economy transition in 28 member states of the European Union. Based on 27 indicators a synthetic Green Economy Index was designed for each country. This allowed for the creation of rankings and comparisons between EU countries in 2010 and 2018. The analyses provided responses to the following questions: (1) Have EU countries achieved progress in implementing the assumptions of a green economy from the introduction of the Europe 2020 strategy? (2) Which countries perform better and which perform worse in that respect? (3) What are the challenges that EU countries must face in the context of greening socio-economic processes?

The theoretical contribution of this paper is to organie the existing knowledge of methods for measuring the green economy at the macro and meso level. Firstly, the author's own contribution comprises of creating a comprehensive tool for measuring the green economy (GEI), preceded by selecting as many as 27 detailed indicators. Previous analyses were based on a maximum of 21 indicators. Secondly, previous research focused mostly on comparing several EU member states. In this study, detailed indicators were selected to ensure a multi-faceted analysis of all member states of the European Union. Thirdly, this is the first time that the evaluation of green transition processes over time is presented in a study.

The paper is organised as follows. Part two conducts a literature review covering the existing research on the methods and results of green economy assessment. The next chapter contains a description of research methods, including the process of designing a synthetic green economy index. Part three, based on GEI, analyses and compares the EU countries, discusses the results and sets the directions for further study. The final part presents conclusions from the analyses.

\section{Literature Review}

Over the past decade, the number of publications devoted to green economy has considerably increased. These surveys mainly investigated: the origin, conditions and the essence of GE [5-14]; the formulation of the GE development strategy at various management levels [4,15-20]; the presentation of good practices and models for implementing GE [21-28] and the comparison of a green economy with other concepts of socio-economic development $[5,6,9,10,18,19,29-31]$. Particular attention was also paid to monitoring and evaluating the assumptions of green economy [3,7,32-46].

The first initiative to measure and evaluate green economy was a study in Taiwan [36]. It relied on indicators based on the ecological footprint and energy consumption analyses. Its results led to a conclusion that the rapid development of the Taiwanese economy at that time was based on the overexploitation of natural resources.

Studies of European and international environmental protection organisations present a more comprehensive approach to methods of measuring green economy. In 2012, one of the largest such institutions, the European Environment Agency (EEA), devoted its report to indicators that could be the measures of green economy [33]. The EEA worked out a method for measuring environmental issues relying on the following set of indicators: D-Driving force indicators; P-Pressure indicators; S-State indicators; I-Impact indicators; and $\mathrm{R}$-Response indicators.

The UNEP is another organisation that proposes a set of indicators to measure green economy progress. UNEP focuses on using green growth indicators to adopt an integrated method for developing green economic policies. The proposed set of indicators includes 
three areas. The first area consists of indicators which evaluate the quality of the environment, risks and positive trends, as well as measuring progress in achieving a specific environmental objective. The second comprises indicators showing the effect of measures undertaken by state governments, that is, indicators evaluating the effectiveness of the state policy. The third area is the impact of green economy on the quality of human life and social inequality [35].

In 2010, a US consulting company, Dual Citizen, created and published the first synthetic index called the Global Green Economy Index [41]. This index relies on quantitative and qualitative indicators to measure the efficiency of green economy in four main dimensions: leadership and climate change, efficiency sectors, markets and investment and the environment. It is a comprehensive analytical tool offering a system for observing, analysing and improving efficiency and image under a green economy [47].

An attempt to create a synthetic index for green economy was also undertaken by B. Ryszawska [3]. The index proposed by the author was designed based on 21 indicators (used by international organisations to evaluate green growth, green economy and sustainable development) grouped into seven areas (I. Ecosystems, biodiversity, and natural capital; II. Emissions, pollution, and waste; III. Consumption of resources; IV. Poverty and social inequality; V. Economy; VI. Policy and environmental strategies; VII. Green economy sectors).

In turn, under the so-called Partnership for Action on Green Economy (PAGE), the Green Economy Progress (GEP) indicator was designed based on thirteen indicators to measure the progress of green economy in respective countries in economic, social and environmental aspects. The indicators taken into account refer to: green patents, renewable energy sources, access to essential services, material footprint, air pollution and gender inequality index [39].

In turn, Cabernard anf Pfister [46] used the new indicators for carbon, water stress, and land-use related biodiversity loss footprints to the GEP evaluation. They proposed the environmentally extended multi-regional input-output (MRIO) database. The database covered 189 countries with a state-of-the-art set of environmental and socio-economic indicators from 1995-2015. The results for the EU27 revealed a significant increase in the EU water stress footprint and biodiversity loss.

In Switzerland, green economy progress is measured using a small set of indicators illustrating the footprint of Switzerland with a particular focus on transformation in the sectors of consumption and production, as well as wastes and commodities [38].

Adequate measures are required for implementing and monitoring green economy in respective countries. Environmental, social and economic indicators aligned with the areas of green economy, selected based on their definitions, make it possible to create a specific set of indicators or a multi-dimensional synthetic index. Georgeson et al. [7], based on their analyses, formulated four key recommendations to improve the methods of measuring green economy, i.e., using progress measures other than the GDP; the wider measurement of interactions between the economy, society and the environment; the better economic measurement of transition to a green economy; and an alternative approach to measurement through seeking new methods and data sources. In turn, Vukovic et al. [43] compiled a list of criteria for evaluating the development of green economy on a regional scale based on the formulated methodology, hierarchical structure of elements of the green economy, and indicators. The list was divided into types and significance levels and could be used both for evaluating the current state of each area separately or forecasting the regional development of a green economy.

As underlined by R. Alekna and E. Kazlauskiene [44], the evaluation of a green economy by the academic community does not always reflect the facts due to the absence of data for respective indicators or limited methods of evaluation. These authors selected fifteen indicators to analyse the green economies of the Baltic countries. The standardisation and further evaluation of these indicators, from the perspective of a green economy, made 
it possible to determine the significance of social, economic and environmental dimensions, in terms of the synthetic green economy index, and illustrated changes in time.

The transition to a green economy is a multi-step process contributing to achieving the long-term objective-sustainable development. Plausibly, correctly selected and current data concerning GE are a significant element for shaping development strategies and using instruments which stimulate changes. Creating a uniform, and at the same time comprehensive, set of indicators to evaluate green economy progress is difficult due to the complexity of the concept alone. Most authors agree that indicators must be based on strict criteria, and should be repeatable, generally accepted, and clear $[48,49]$.

\section{Materials and Methods}

In contrast to the observation of single indicators, the synthetic index allows for the evaluation of the studied phenomenon in a comprehensive manner in respective countries, grouping them according to achieved progress, making international comparisons, and observing changes in time [50]. The conceptual framework for the construction and empirical verification of the GEI index includes the following steps:

1. The selection of the partial indicators describing the green economy;

2. The standardisation of the indicators according to their impact (stimulants/destimulants) on the phenomenon studied ('green' transformation of the EU countries);

3. The construction of the synthetic measure and the GEI indexes for respective countries;

4. The linear hierarchisation of the EU countries in 2010 and 2018, based on the GEI.

The procedure applied in the work relies on a multifaceted comparative analysis $(M C A)$ allowing comparisons between objects (e.g., countries, regions, and enterprises) described by multiple features [51] (p. 250). It is especially predisposed to explore complex phenomena described by many variables. One division of multifaceted comparative analysis is the so-called taxonomic methods [52-54]. The GEI is designed with a taxonomic method of linear ordering using the median and standard deviation. This method features a high resistance to extreme observations, which is particularly important in the comparative analysis of EU countries. Respective countries often differ significantly and show considerable disparities in the asymmetry of indicator values. Therefore, using a synthetic metric with the median is highly relevant [55-57].

\subsection{Selecting a Set of Indicators}

At the first stage of creating the Green Economy Index, according to MCA, the study of objects and variables describing the specific object was identified. The objects of study in this case were 28 member states of the European Union (as at 2018). The variables were selected to ensure that they reflected various aspects of green economy, expressed in their definitions, to the fullest extent possible. The selection of variables, according to M. Walesiak, was one of the most important and, at the same time, most difficult things. The quality of variables determined the relevance of the final results and the accuracy of the decisions based on them. Normally, the list of indicators was long; the dilemma was how to choose the right set. The set of indicators was unlimited, so a targeted selection matching the respective issue was necessary [58] (p. 55); [3] (p. 102).

Creating a set of indicators for designing the synthetic index, GEI, mostly relied on the previous experience of international organisations and entities testing green economy measurement methods, such as: UNO (UNEP, PAGE), European Environment Agency, OECD, and Dual Citizens Inc. The sets of indicators proposed by these organisations often form the basis for national green economy measurement frameworks. It would therefore be difficult to make international comparisons of the greening of the economy based on assessments made by individual countries. In order to carry out such an analysis, existing studies and indicator databases were used to standardise the set of indicators for all EU countries. This made sense, as the indicator proposals published by international environmental organisations were developed by independent experts. This way, 38 detailed indicators for respective areas of green economy (environment-economy-society) were identified. 
The next step was to check whether reliable data on selected indicators were available for all the $28 \mathrm{EU}$ member states. It turned out that 27 indicators (71\%) satisfied this condition and were finally used in designing the GEI (Table 1). Statistics regarding respective indicators were derived from the Eurostat databases and the OECD. The time horizon was from 2010 (base year in which the Europa 2020 strategy was put into effect) to 2018 (latest data available for all $28 \mathrm{EU}$ member states). Since some indicators were expressed in absolute terms, to ensure their comparability, they were relativised, for instance, by converting them into units of the surface area of a specific country or calculating them per capita. It was worth highlighting that in the selected set of detailed indicators those related to energy efficiency $\left(x_{4}-x_{8}, x_{11}\right)$ played an important role. They accounted for more than $20 \%$ of all indicators, so their effect on the final values of green economy indices in respective countries was significant.

Table 1. Indicators selected for the analysis.

\begin{tabular}{|c|c|c|c|}
\hline $\begin{array}{l}\text { Indicator } \\
\text { Symbol }\end{array}$ & Indicator Name (Unit of Measure) & Source & $\begin{array}{c}\text { Stimulant/ } \\
\text { Destimulant }\end{array}$ \\
\hline$x_{1}$ & Greenhouse gas emissions (tonnes per capita) & $\begin{array}{l}\text { UNEP; Ryszawska; Dual Citizen } \\
\text { LLC; Eurostat }\end{array}$ & $\mathrm{D}$ \\
\hline$x_{2}$ & Sulphur oxides (SO2) emissions (kg per capita) & $\begin{array}{l}\text { Ryszawska; Dual Citizen } \\
\text { LLC; Eurostat }\end{array}$ & $\mathrm{D}$ \\
\hline$x_{3}$ & Mean population exposure to PM2.5 (micrograms $/ \mathrm{m}^{3}$ ) & PAGE; OECD & $\mathrm{D}$ \\
\hline$x_{4}$ & Primary energy consumption (TOE ${ }^{1}$ per capita) & UNEP; Ryszawska; PAGE; Eurostat & $\mathrm{D}$ \\
\hline$x_{5}$ & Final energy consumption (TOE per capita) & PAGE; Eurostat & $\mathrm{D}$ \\
\hline$x_{6}$ & Renewable energy supply (\% total energy supply) & $\begin{array}{l}\text { UNEP; Dual Citizen LLC; PAGE; } \\
\text { Ryszawska; OECD }\end{array}$ & $\mathrm{S}$ \\
\hline$x_{7}$ & Share of renewable energy in gross final energy consumption (\%) & Eurostat & S \\
\hline$x_{8}$ & Renewable electricity (\% total electricity generation) & Dual Citizen LLC; OECD & S \\
\hline$x_{9}$ & $\begin{array}{l}\text { Production-based and demand-based } \mathrm{CO}_{2} \text { productivity (US } \\
\text { dollars per kilogram } \mathrm{CO}_{2}, 2015 \text { ) }\end{array}$ & UNEP; OECD & $\mathrm{S}$ \\
\hline$x_{10}$ & Resource productivity (purchasing power standard per kilogram) & $\begin{array}{l}\text { UNEP; Ryszawska; Dual Citizen } \\
\text { LLC; Eurostat }\end{array}$ & $\mathrm{S}$ \\
\hline$x_{11}$ & Energy productivity (euro per kilogram of oil equivalent) & UNEP; Eurostat & S \\
\hline$x_{12}$ & Environmental tax revenues (\% GDP ${ }^{2}$ ) & UNEP; Ryszawska; Eurostat & $\mathrm{S}$ \\
\hline$x_{13}$ & $\begin{array}{l}\text { Development of environment-related technologies } \\
\text { (\% all technologies) }\end{array}$ & $\begin{array}{l}\text { UNEP; Ryszawska; Dual Citizen } \\
\text { LLC; OECD }\end{array}$ & $\mathrm{S}$ \\
\hline$x_{14}$ & Eco-innovation index (score) & Eurostat & $\mathrm{S}$ \\
\hline$x_{15}$ & Generation of waste (kg per capita) & UNEP; Ryszawska; Eurostat & $\mathrm{D}$ \\
\hline$x_{16}$ & Recycling waste (tonnes per capita) & UNEP; Ryszawska; Eurostat & S \\
\hline$x_{17}$ & Circular material use rate (\%) & Eurostat & S \\
\hline$x_{18}$ & Terrestrial protected area ( $\%$ of total area) & UNEP; PAGE; OECD & S \\
\hline$x_{19}$ & Area under organic farming (\% of utilised agricultural area) & Ryszawska; Eurostat & $\mathrm{S}$ \\
\hline$x_{20}$ & Water exploitation index (\%) & UNEP; Dual Citizen LLC; Eurostat & $\mathrm{D}$ \\
\hline$x_{21}$ & Real GDP per capita (US Dollar, 2015) & Ryszawska; OECD & $\mathrm{S}$ \\
\hline$x_{22}$ & The Global Competitiveness Index (0-100) & Ryszawska; OECD & $S$ \\
\hline$x_{23}$ & Life expectancy at birth (number of years) & PAGE; OECD & S \\
\hline$x_{24}$ & Population, ages 15-64 (\% total) & OECD & $\mathrm{S}$ \\
\hline$x_{25}$ & Unemployment rate $(\%)$ & Ryszawska; OECD & $\mathrm{D}$ \\
\hline$x_{26}$ & People at risk of poverty or social exclusion (\%) & Ryszawska; Eurostat & $\mathrm{D}$ \\
\hline$x_{27}$ & Gini coefficient of equivalised disposable income $(0-100)$ & UNEP; Ryszawska; Eurostat & $\mathrm{D}$ \\
\hline
\end{tabular}

${ }^{1}$ TOE-tonne of oil equivalent; ${ }^{2}$ GDP—gross domestic product. Source: own elaboration based on: UNEP, 2012; Ryszawska, 2013a; PAGE, 2017; Dual Citizen LLC, 2018; the OECD and Eurostat database. 


\subsection{Standardisation of the Indicators}

According to the information given in Table 1 , the set of variables contained stimulants, that is, variables with a positive impact on a specific phenomenon (the higher value the better), and destimulants that delayed and decelerated the development of the phenomenon (the lower value the better) [3,57]. For instance, greenhouse gas emissions were undesirable from the point of view of the green economy, so this indicator was a typical destimulant. In other words, the higher the emission, the lower the rating of green economy in the specific country (lower GEI). On the other hand, from the point of view of green economy, a high share of renewable energy sources was desirable, so $x_{7}$ was a typical stimulant. The higher the value of this indicator, the higher the rating of green economy (higher GEI) for the specific country.

The values of variables $(X j, j=1,2, \ldots, m)$ describing the studied objects (EU countries) $(\mathrm{O} i, i=1,2, \ldots, n)$ are presented as a matrix of observations in the following form (Equation (1)):

$$
X=\left[\begin{array}{ccc}
x_{11} & \cdots & x_{1 m} \\
\vdots & \ddots & \vdots \\
x_{n 1} & \cdots & x_{n m}
\end{array}\right]
$$

for example: $x_{11}$-is the value of variable 1 in country 1 .

Since the set of detailed indicators contained variables that could not be directly aggregated (different units of measure), they were standardised using the zero unitarisation method (Equations (2) and (3)) [59-62]:

For stimulants:

$$
z_{i j}=\frac{x_{i j}-\min \left(x_{i j}\right)_{i}}{\max \left(x_{i j}\right)_{i}-\min \left(x_{i j}\right)_{i}}
$$

For de-stimulants:

$$
z_{i j}=\frac{\max \left(x_{i j}\right)_{i}-x_{i j}}{\max \left(x_{i j}\right)_{i}-\min \left(x_{i j}\right)_{i}}
$$

where:

$z_{i j}$ is the normalised value of the $j$-th variable in the $i$-th country

$x_{i j}$ is the initial value of the $j$-th variable in the $i$-th country

$\min \left(x_{i j}\right)_{i}$ is the minimum value of $x_{i j}$

$\max \left(x_{i j}\right)_{i}$ is the maximum value of $x_{i j}$

This method was the only one satisfying all of the seven postulates formulated with reference to the variables' standardising procedure [63]. After scaling all values, $z_{i j}$ fell into the $[0,1]$ range and were deprived of units, so they could be added and compared. Values closer to 1 meant that the specific variable (indicator) was better and, conversely, values closer to 0 meant that the specific indicator was worse, and thus the GEI for the given country was lower.

\subsection{GEI Index Construction}

In the next step, the standardised values of detailed indicators were used as a basis for computing the medians (Equations (4) and (5)) and standard deviations (Equation (6)) $[55,56,64]$ :

$$
M e_{i}=\frac{z_{\left(\frac{m}{2}\right) i}+z_{\left(\frac{m}{2}+1\right) i}}{2}
$$

for an even number of observations $(m)$, or:

$$
M e_{i}=z_{\left(\frac{m}{2}+1\right) i}
$$

for an odd number of observations $(m)$, where:

$z_{i(j)}$ is the $j$-th statistical ordinal for the vector $\left(z_{i 1}, z_{i 2}, \ldots, z_{i m}\right), i=1,2, \ldots, n ; j=1$, $2, \ldots, m$. 


$$
S e_{i}=\sqrt{\frac{1}{m} \sum_{j=1}^{m}\left(z_{i j}-\bar{z}\right)}
$$

where:

$\bar{z}$ is the mean value for $z_{i j}$.

The last step, based on the following Equation (7), was to calculate the green economy indices $\left(G E I_{i}\right)$ for each of the EU member states in 2010 and 2018:

$$
G E I_{i}=M e_{i}\left(1-S e_{i}\right) G E I_{i}<1
$$

The values of GEI closer to 1 pointed to a relatively higher level of transition of the specific country to a green economy. The estimated synthetic measures allowed for a comparative analysis of EU countries to be conducted in the study years and evaluated the changes that occurred in 2018, in comparison to the base year. The respective countries were assigned into four groups showing a similar level of transition, as follows:

$$
\begin{gathered}
\text { group I : } G E I_{i} \geq \overline{G E I}+S \text { high level } \\
\text { group II }: \overline{G E I}+S>G E I_{i} \geq \overline{G E I} \text { medium-high level } \\
\text { group III : } \overline{G E I}>G E I_{i} \geq \overline{G E I}-S \text { medium-low level } \\
\text { group IV : } \quad G E I_{i}<\overline{G E I}-S \text { low level }
\end{gathered}
$$

where $\overline{G E I}$ is the mean value of green economy indices for 28 member states, and $S$ is a standard deviation of these indices.

The final step concerning the linear hierarchy of EU countries in 2010 and 2018 is discussed in the results section.

\section{Results and Discussion}

Green Economy Indexes calculated for 28 member states of the European Union in 2010 and in 2018 are presented in Figure 1 and in Table 2. Respective shades of green on the charts denote the allocation of respective countries into one of four groups with different ratings of the 'green' transition.

The average GEI in 2018 for all the analysed countries was 0.3294 , and in the base year it was 0.3423 , which meant that in the analysed years the general level of 'greening' of the economies in EU member states decreased. It should be emphasised that this level was very low considering the possible range of GEI (0.1). Standard deviations of the indices for EU member states (0.0989 in 2018 and 0.0988 in 2010) testify to a high differentiation of 'green' transition processes in respective countries.

In 2018, the highest GEI was noted in Denmark (0.5415), and the lowest in Bulgaria (0.1038). In 2010, Denmark was in 4th place in the ranking of EU member states, while Austria achieved the best score (0.5194). As in 2018, Bulgaria ranked last in 2010 (0.1315).

The analysis of the four groups of countries showed that, in 2018, Group I, featuring the highest level of green economy transition, consisted of five member states: Denmark, Austria, Sweden, France and the Netherlands. In comparison to 2010, no change in quantity occurred. The only difference was that the Netherlands moved to Group I, replacing the United Kingdom. However, major changes could be observed in Group IV consisting of countries with the lowest GEI. In 2018, next to Bulgaria, this group included Hungary and Romania, and in 2010, Lithuania and Slovakia. Invariably, in the study years Group III was the most numerous group of EU member states (12) featuring, on average, low green economy ratings. 


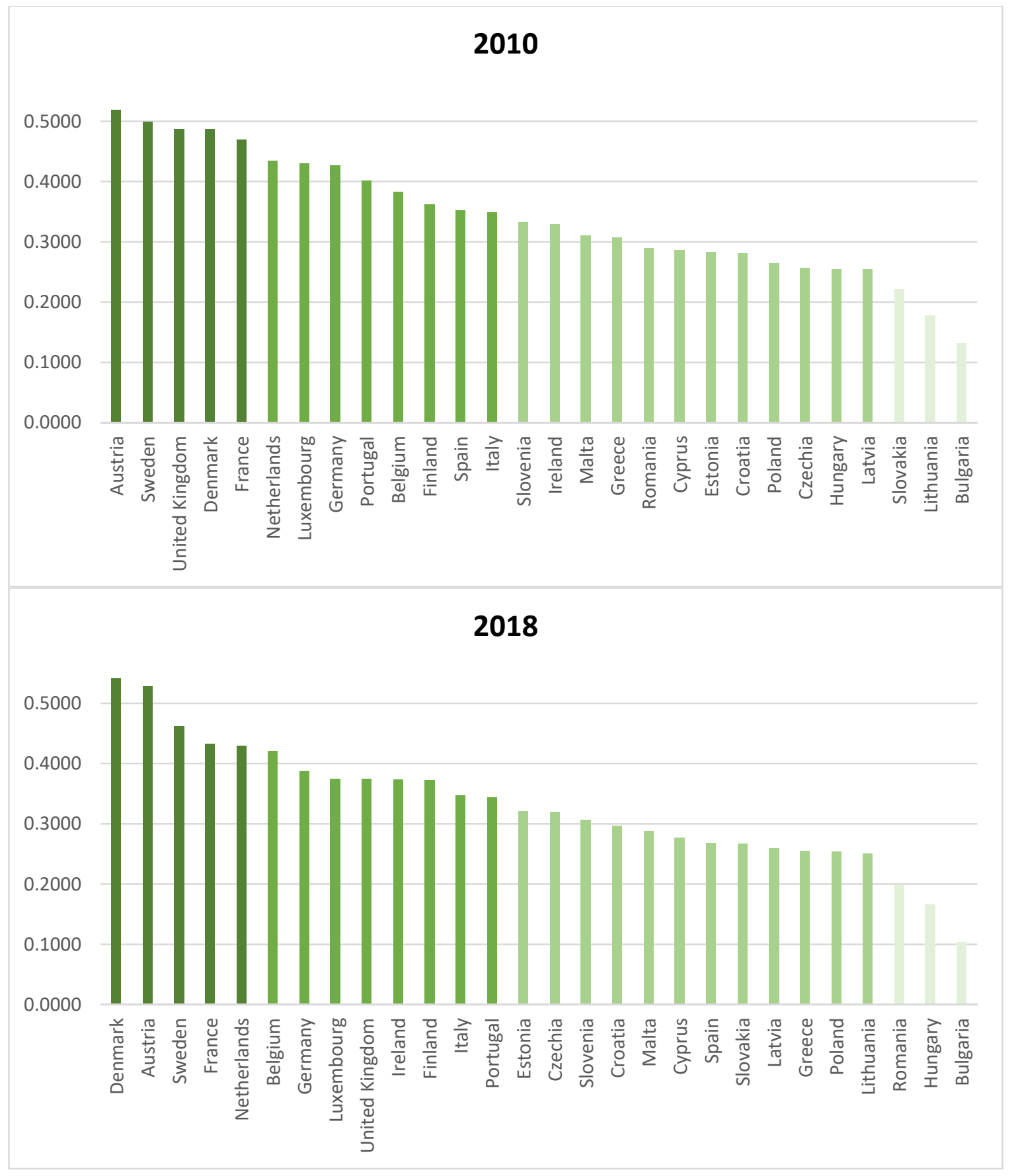

Figure 1. EU countries ranking based on GEI in 2010 and 2018. Source: own calculation.

In the ranking of the EU countries, 13 of them moved to a higher group in the study years and 12 moved to a lower group, while three countries maintained their status quo (Table 2). The Czech Republic noted the highest advance in the ranking (+8 places) but did not move to a higher rating group. In turn, the largest decreases were observed for Romania (-8) and Spain $(-8)$, where both countries moved to lower rating groups.

Which factors decreased the general level of 'greening' of the economies of the EU countries? A deeper analysis of the mean values of the synthetic measures of detailed indicators in the study years led to a conclusion that these values decreased for 15 of them (55.6\%). Negative changes mostly affected the following indicators:

- Energy productivity: 0.4127 in 2010 vs. 0.3079 in 2018 (-25\%);

- People at risk of poverty or social exclusion: 0.7054 vs. $0.5338(-24 \%)$; 
- Production-based and demand-based CO2 productivity: 0.4275 vs. $0.3507(-18 \%)$;

- The development of environment-related technologies: 0.4590 vs. $0.4057(-12 \%)$;

- $\quad$ Resource productivity: 0.4107 vs. $0.3658(-11 \%)$;

- Renewable energy supply: 0.3746 vs. $0.3338(-11 \%)$;

- The share of renewable energy in gross final energy consumption: 0.3279 vs. $0.2910(-11 \%)$.

Thus, it is clear that a general decrease in the level of 'greening' of the economies of the EU member states was primarily due to lower values of energy efficiency, social indicators, $\mathrm{CO} 2$ productivity and resources productivity indicators. The identified areas required intensive monitoring and corrective measures to be undertaken by international and national institutions in the following years.

Table 2. Green economy in EU countries in 2010 and 2018.

\begin{tabular}{|c|c|c|c|c|c|}
\hline \multirow[b]{2}{*}{ EU Countries } & \multicolumn{2}{|c|}{2010} & \multicolumn{2}{|c|}{2018} & \multirow{2}{*}{$\begin{array}{c}\text { Ranking } \\
\text { Change } \\
2010 \text { vs. } 2018\end{array}$} \\
\hline & $\begin{array}{l}\text { GE Level } \\
\text { (Group) }\end{array}$ & $\begin{array}{c}\text { EU Countries } \\
\text { Ranking }\end{array}$ & $\begin{array}{l}\text { GE Level } \\
\text { (Group) }\end{array}$ & $\begin{array}{c}\text { EU Countries } \\
\text { Ranking }\end{array}$ & \\
\hline Austria & I & 1 & I & 2 & -1 \\
\hline Belgium & II & 10 & II & 6 & +4 \\
\hline Bulgaria & IV & 28 & IV & 28 & 0 \\
\hline Croatia & III & 21 & III & 17 & +4 \\
\hline Cyprus & III & 19 & III & 19 & 0 \\
\hline Czech Republic & III & 23 & III & 15 & +8 \\
\hline Denmark & I & 4 & $\mathrm{I}$ & 1 & +3 \\
\hline Estonia & III & 20 & III & 14 & +6 \\
\hline Finland & II & 11 & II & 11 & 0 \\
\hline France & $\mathrm{I}$ & 5 & $\mathrm{I}$ & 4 & +1 \\
\hline Germany & II & 8 & II & 7 & +1 \\
\hline Greece & III & 17 & III & 23 & -6 \\
\hline Hungary & III & 24 & IV & 27 & -3 \\
\hline Ireland & III & 15 & II & 10 & +5 \\
\hline Italy & II & 13 & II & 12 & +1 \\
\hline Latvia & III & 25 & III & 22 & +3 \\
\hline Lithuania & IV & 27 & III & 25 & +2 \\
\hline Luxembourg & II & 7 & II & 8 & -1 \\
\hline Malta & III & 16 & III & 18 & -2 \\
\hline Netherlands & II & 6 & I & 5 & +1 \\
\hline Poland & III & 22 & III & 24 & -2 \\
\hline Portugal & II & 9 & II & 13 & -4 \\
\hline Romania & III & 18 & IV & 26 & -8 \\
\hline Slovak Republic & IV & 26 & III & 21 & +7 \\
\hline Slovenia & III & 14 & III & 16 & -2 \\
\hline Spain & II & 12 & III & 20 & -8 \\
\hline Sweden & $\mathrm{I}$ & 2 & I & 3 & -1 \\
\hline United Kingdom & $\mathrm{I}$ & 3 & II & 9 & -6 \\
\hline
\end{tabular}

Source: own elaboration.

Based on 2018 only, the indicators that performed very well could be identified. For the lowest values of synthetic measures of detailed indicators, the following should be noted:

- the low emissions of $\mathrm{SO}_{2}-0.9184$;

- the still low water exploitation index-0.8692, although it should be underlined that, in comparison to 2010, a deterioration by more than $4 \%$ of the value of this index was noted; 
- $\quad$ a decrease in final energy consumption-0.7962;

- a decrease in the amount of waste produced per capita-0.7513;

- a large decrease in unemployment-0.7482, which was associated with EU countries gradually recovering from the financial and economic crisis (2008).

On the other hand, the lowest values of synthetic measures of detailed indicators were noted for:

- $\quad$ waste recycling level-0.1866;

- GDP per capita-0.2431;

- the utilisation of circular materials-0.2789;

- the share of renewable energy in gross final energy consumption-0.2910;

- $\quad$ energy productivity-0.3079.

Table 3 shows detailed indicators for respective countries (representing specific areas of green economy) that need corrective measures. It is assumed that a specific area needs such measures if the standardised value of the indicator in the given country is lower than 0.4 . $(z i j<0.4000)$. The table clarifies which challenges respective countries must face in relation to the green economy.

Table 3. Challenges for EU countries on the road to GE.

\begin{tabular}{|c|c|}
\hline EU Countries & Indicators (Areas) Requiring Corrective Actions $\left(z_{i j}<0.4000\right)$ \\
\hline Austria & $x_{9} ; x_{10} ; x_{12} ; x_{13} ; x_{16} ; x_{17} ; x_{18} ; x_{21}$ \\
\hline Belgium & $x_{6} ; x_{7} ; x_{8} ; x_{9} ; x_{11} ; x_{13} ; x_{16} ; x_{18} ; x_{19} ; x_{21} ; x_{24}$ \\
\hline Bulgaria & $x_{3} ; x_{6} ; x_{7} ; x_{8} ; x_{9} ; x_{10} ; x_{11} ; x_{14} ; x_{15} ; x_{16} ; x_{17} ; x_{19} ; x_{21} ; x_{22} ; x_{23} ; x_{24} ; x_{26} ; x_{27}$ \\
\hline Croatia & $x_{3} ; x_{9} ; x_{10} ; x_{11} ; x_{13} ; x_{16} ; x_{17} ; x_{19} ; x_{21} ; x_{22}$ \\
\hline Cyprus & $x_{6} ; x_{7} ; x_{8} ; x_{9} ; x_{10} ; x_{11} ; x_{13} ; x_{14} ; x_{16} ; x_{17} ; x_{19} ; x_{21} ; x_{22}$ \\
\hline Czech Republic & $x_{3} ; x_{6} ; x_{7} ; x_{8} ; x_{9} ; x_{10} ; x_{11} ; x_{12} ; x_{16} ; x_{17} ; x_{18} ; x_{21}$ \\
\hline Denmark & $x_{2} ; x_{10} ; x_{16} ; x_{17} ; x_{18} ; x_{19} ; x_{21} ; x_{24}$ \\
\hline Estonia & $x_{1} ; x_{6} ; x_{8} ; x_{9} ; x_{10} ; x_{11} ; x_{14} ; x_{15} ; x_{18} ; x_{21} ; x_{24}$ \\
\hline Finland & $x_{4} ; x_{9} ; x_{10} ; x_{11} ; x_{15} ; x_{16} ; x_{17} ; x_{18} ; x_{21} ; x_{24}$ \\
\hline France & $x_{6} ; x_{7} ; x_{8} ; x_{11} ; x_{12} ; x_{13} ; x_{16} ; x_{18} ; x_{19} ; x_{21} ; x_{24}$ \\
\hline Germany & $x_{6} ; x_{7} ; x_{8} ; x_{9} ; x_{12} ; x_{16} ; x_{17} ; x_{19} ; x_{21} ; x_{24}$ \\
\hline Greece & $x_{6} ; x_{7} ; x_{8} ; x_{9} ; x_{10} ; x_{11} ; x_{16} ; x_{17} ; x_{19} ; x_{21} ; x_{22} ; x_{24} ; x_{25} ; x_{26} ; x_{27}$ \\
\hline Hungary & $x_{3} ; x_{6} ; x_{7} ; x_{8} ; x_{9} ; x_{10} ; x_{11} ; x_{12} ; x_{13} ; x_{14} ; x_{16} ; x_{17} ; x_{18} ; x_{19} ; x_{20} ; x_{21} ; x_{22} ; x_{23}$ \\
\hline Ireland & $x_{6} ; x_{7} ; x_{8} ; x_{12} ; x_{13} ; x_{16} ; x_{17} ; x_{18} ; x_{19} ; x_{24}$ \\
\hline Italy & $x_{3} ; x_{6} ; x_{7} ; x_{9} ; x_{13} ; x_{16} ; x_{18} ; x_{21} ; x_{24} ; x_{26} ; x_{27}$ \\
\hline Latvia & $x_{9} ; x_{10} ; x_{11} ; x_{13} ; x_{14} ; x_{16} ; x_{17} ; x_{18} ; x_{21} ; x_{22} ; x_{23} ; x_{24} ; x_{26} ; x_{27}$ \\
\hline Lithuania & $x_{7} ; x_{10} ; x_{11} ; x_{12} ; x_{13} ; x_{16} ; x_{17} ; x_{18} ; x_{19} ; x_{21} ; x_{22} ; x_{23} ; x_{24} ; x_{26} ; x_{27}$ \\
\hline Luxembourg & $x_{1} ; x_{4} ; x_{5} ; x_{6} ; x_{7} ; x_{9} ; x_{12} ; x_{15} ; x_{17} ; x_{19}$ \\
\hline Malta & $x_{6} ; x_{7} ; x_{8} ; x_{11} ; x_{14} ; x_{16} ; x_{17} ; x_{18} ; x_{19} ; x_{21} ; x_{22}$ \\
\hline Netherlands & $x_{6} ; x_{7} ; x_{8} ; x_{9} ; x_{11} ; x_{13} ; x_{18} ; x_{19} ; x_{21} ; x_{24}$ \\
\hline Poland & $x_{3} ; x_{6} x_{7} ; x_{8} ; x_{9} ; x_{10} ; x_{11} ; x_{13} ; x_{14} ; x_{16} ; x_{17} ; x_{19} ; x_{21} ; x_{22}$ \\
\hline Portugal & $x_{9} ; x_{10} ; x_{11} ; x_{13} ; x_{16} ; x_{17} ; x_{18} ; x_{19} ; x_{21} ; x_{24}$ \\
\hline Romania & $x_{6} ; x_{7} ; x_{9} ; x_{10} ; x_{11} ; x_{12} ; x_{13} ; x_{14} ; x_{16} ; x_{17} ; x_{18} ; x_{19} ; x_{21} ; x_{22} ; x_{23} ; x_{26} ; x_{27}$ \\
\hline Slovak Republic & $x_{3} ; x_{6} ; x_{7} ; x_{8} ; x_{9} ; x_{10} ; x_{11} ; x_{12} ; x_{14} ; x_{16} ; x_{17} ; x_{19} ; x_{21} ; x_{22} ; x_{23}$ \\
\hline Slovenia & $x_{3} ; x_{6} ; x_{7} ; x_{8} ; x_{9} ; x_{10} ; x_{11} ; x_{13} ; x_{16} ; x_{17} ; x_{19} ; x_{21}$ \\
\hline Spain & $x_{6} ; x_{7} ; x_{9} ; x_{11} ; x_{12} ; x_{13} ; x_{16} ; x_{17} ; x_{18} ; x_{19} ; x_{21} ; x_{25} ; x_{26} ; x_{27}$ \\
\hline Sweden & $x_{10} ; x_{11} ; x_{12} ; x_{16} ; x_{17} ; x_{18} ; x_{19} ; x_{21} ; x_{24}$ \\
\hline United Kingdom & $x_{6} ; x_{7} ; x_{8} ; x_{12} ; x_{16} ; x_{18} ; x_{19} ; x_{21} ; x_{24} ; x_{27}$ \\
\hline
\end{tabular}

Denmark, which scored the best value for GEI in 2018, owes its success to high scores for 15 indicators (more than 55\%). However, in this country there are some areas that 
need special attention for the monitoring institutions. These areas primarily include: $\mathrm{SO}_{2}$ emissions (the worst score in Europe), the low percentage share of protected areas in the total surface area of the country, relatively low waste recycling indicators in comparison to other countries, a high percentage of non-productive-age population and low utilisation of circular materials and resource productivity.

The results can be compared with the analysis carried out by a US company Dual Citizen Inc. [65]. Since 2010 it has created and published annual reports on the so-called Global Green Economy Index (GGEI). Initially, the reports covered only 27 countries internationally. The latest report for 2018 compared 130 countries, including $28 \mathrm{EU}$ member states. Differences between GGEI and GEI presented here were significant and refer to the quantity and type of selected detailed indicators. The GGEI consisted of 20 base indicators under four previously mentioned areas-leadership and climate change, efficiency sectors, markets and investment and the environment. Table 4 compares the rankings of EU countries based on GGEI and GEI. In both of them Bulgaria ranked last. The top ten in both rankings contained the same nine countries and the last ten contained six.

Table 4. Comparison of the rankings of EU countries based on Global Green Economy Index (Dual Citizen Inc.), Green Economy Index (Kasztelan) and Green Economy Progress (PAGE).

\begin{tabular}{|c|c|c|}
\hline $\begin{array}{c}\text { GGEI } \\
2018\end{array}$ & $\begin{array}{c}G E I \\
2018\end{array}$ & $\begin{array}{c}G E P^{1} \\
2004-2014\end{array}$ \\
\hline Sweden & Denmark & Bulgaria \\
\hline Finland & Austria & Slovenia \\
\hline Germany & Sweden & Hungary \\
\hline Denmark & France & Ireland \\
\hline Austria & Netherlands & Poland \\
\hline France & Belgium & Cyprus \\
\hline United Kingdom & Germany & Luxembourg \\
\hline Ireland & Luxembourg & Italy \\
\hline Netherlands & United Kingdom & Spain \\
\hline Belgium & Ireland & Greece \\
\hline Italy & Finland & Belgium \\
\hline Greece & Italy & France \\
\hline Hungary & Portugal & Germany \\
\hline Spain & Estonia & United Kingdom \\
\hline Portugal & Czech Republic & Croatia \\
\hline Luxembourg & Slovenia & Czech Republic \\
\hline Malta & Croatia & Netherlands \\
\hline Lithuania & Malta & Austria \\
\hline Slovenia & Cyprus & Finland \\
\hline Croatia & Spain & Portugal \\
\hline Romania & Slovak Republic & Estonia \\
\hline Czech Republic & Latvia & Denmark \\
\hline Estonia & Greece & Sweden \\
\hline Latvia & Poland & Slovak Republic \\
\hline Slovak Republic & Lithuania & Lithuania \\
\hline Cyprus & Romania & Latvia \\
\hline Poland & Hungary & \\
\hline Bulgaria & Bulgaria & \\
\hline
\end{tabular}

${ }^{1}$ No data available for Malta and Romania. Source: own elaboration, Dual Citizen LLC [65] and PAGE [40].

Another point of reference for the results could be, to some extent, the analyses carried out by Ryszawska [3]. The author designed and verified using empirical methods the 
green economy index for $27 \mathrm{EU}$ member states (excluding Croatia). Data on 21 indicators collected for analyses referred to different years from the 2009-2012 interval, so these comparisons should be treated very carefully. This was even more justified since the methods used to design the synthetic index were also different. Despite these differences, certain similarities with the results for 2010 were found. The top ten in the ranking by Ryszawska contained eight countries that were also classified in the GEI ranking: Sweden, the Netherlands, Denmark, Austria, Germany, United Kingdom, Belgium, and France. In turn, the last ten were similar as they contained seven countries: Estonia, the Czech Republic, Poland, Slovakia, Romania, Cyprus and Bulgaria.

The Green Economy Progress (GEP) index was developed under PAGE [39]. This index, in contrast to previously presented solutions, relied on 13 indicators mostly describing changes in the transition to a green economy. It was used for calculating GEP indices for 105 countries, including 26 EU member states (except for Malta and Romania) in the period 2004-2014 [40]. Due to a completely different design of this index, the ranking of EU member states looked completely different (Table 4). The biggest progress in implementing the assumptions of a green economy in the study years was achieved by: Bulgaria, Slovenia, Hungary, Ireland and Poland. In turn, the smallest progress was noted in Latvia, Lithuania, Slovakia, Sweden and Denmark.

The GEP analysis by Cabernard anf Pfister [46] showed that most countries did not meet their environmental goals, even though they sometimes moved in the right direction. In addition, many countries that projected a significant future population growth had an increasing environmental footprint. This clearly indicated that more needs to be done to transition to a greener economy from a global perspective.

In 2020, Alekna and Kazlauskiene [44] published the results of a study concerning the green economy in the Baltic countries: Lithuania, Latvia and Estonia. Based on 15 indicators they calculated green economy indices in 2000-2018. Nevertheless, they did not compare the results of their study with the results for other EU member states. However, it can be concluded that the values of green economy indices in these countries for 2018 significantly differed from values presented in this study, which was certainly due to a limited number of indicators used in the analyses: Estonia-0.65 vs. 0.3205 ; Latvia-0.53 vs. 0.2592; Lithuania- 0.52 vs. 0.2510 . In contrast, the results of both studies corroborated the order in which respective member states appeared in the rankings of the Baltic countries.

Other studies mainly referred to the analysis of selected green economy indicators in specific countries $[7,32,38]$, without designing synthetic indices, so they could not be used in the comparisons.

The use of the synthetic index approach allowed a clear evaluation of the activities undertaken by the EU member states in the area of green economy in the first eight years of the Europe 2020 strategy. On the other hand, the analysis of each detailed indicator forming a part of the GEI allowed for the identification of the strengths and weaknesses of transition both at the level of the EU and in its respective member states.

During the analyses certain limitations occurred which, to some extent, set potential directions for further research. The design of the index was based on 27 indicators even though 38 green economy indicators were initially identified. This was due to the existing information gap in reporting this data by certain countries of the Community. The system solutions aiming to improve the efficiency of gathering data on respective indicators could boost the comprehensive evaluation of measures undertaken by EU member states for the green economy. Secondly, the latest available data on most of the detailed indicators was derived from 2018, so it was impossible to conclude which changes occurred in 2019-2020. At that time, EU member states faced exceptional challenges-primarily associated with the necessity to combat the COVID-19 -pandemic. A question arises of how this affected the dynamics and the present shape of the 'green' transition of the European Union's member states. Thirdly, an interesting direction for further research could be the evaluation of 'green' transformation processes in other countries of the world in order to compare the 
results obtained with EU countries. Finally, due to its design, the GEI could be used in the future to evaluate spatial units at the lower level (regions, voivodeships).

\section{Conclusions}

The assumptions and objectives of the green economy concept were described in the strategic documents of the European Union. Since 2010, green economy has been a key element of the Europe 2020 strategy. A problem related to the development of green economy is how it is monitored at different management levels. Discussion on the methods of evaluating the green economy are pending in the international forum and this study is simply another voice in that discussion.

The evaluation of the processes marking countries' transitions to a green economy is a complex issue that needs advanced methods of analysis. A multifaceted comparative analysis proved to be an adequate tool for designing a synthetic Green Economy Index and for the linear ordering of EU member states. In the course of this research, four groups of countries were identified according to different levels of implementation of the assumptions of the green economy.

The added value of the study comprises, firstly, of developing a comprehensive evaluation method through designing a synthetic GEI, preceded by a thorough analysis of reference literature and the identification of 27 detailed indicators. It should be emphasised that previous analyses were based on a maximum of 21 indicators. The informative value of the GEI should improve integration and activities such as monitoring, planning and implementing the assumptions of green economy in the EU member states. At the same time, the analysis of synthetic detailed indicators allowed for the identification of the strengths and weaknesses of the 'green' transition processes in respective countries. Secondly, previous research in most cases focused on comparing several EU member states. In this study, detailed indicators were selected to ensure a multi-faceted analysis of all countries of the EU member states. Thirdly, this is the first time that an evaluation of the phenomenon of the green economy over time is presented by comparing the results from 2018 with those from the base year (2010).

In response to research questions set forth in this work, it should be concluded that from 2010-2018 a decrease in the mean GEI for EU member states (from 0.3423 to 0.3294 ) was noted, which should be interpreted as a step backwards in the processes of the 'green' transition of Europe. Moreover, it should be underlined that such low index levels testified to a generally low level of the 'greening' of the economies of the EU member states. In response to the second question, out of 28 countries, those that scored the highest for green economy were: Denmark, Austria, Sweden, France and the Netherlands, and those that scored the highest were: Bulgaria, Hungary and Romania. Thirdly, the analysis of mean standardised values of detailed indicators showed that many areas of activity still require determined intervention both at the national and international level.

These research results should contribute to redefining some of the assumptions of European environmental policy. Activities in this area should focus on: the improvement in the energy efficiency, including energy productiveness; a successive increase in the share of renewable energy sources in the energy balance; a continuous reduction in a high percentage of the population at a risk of poverty or social exclusion; the improvement in resources and $\mathrm{CO}_{2}$ productivity, and, ultimately, the achievement of zero-carbon socioeconomic processes.

Funding: This research was funded by the University of Life Sciences, Faculty of Agrobioengineering, grant number RKA/35/2021 (EFI).

Institutional Review Board Statement: Not applicable.

Informed Consent Statement: Not applicable.

Data Availability Statement: The data for the analysis was extracted from OECD and Eurostat database: https:/ / stats.oecd.org/Index.aspx?DataSetCode=GREEN_GROWTH and https:/ / ec.europa. eu/eurostat/data/database (accessed on 15 July 2021). 
Conflicts of Interest: The author declares no conflict of interest.

\section{References}

1. Pearce, D.; Markandya, A.; Barbier, E. Blueprint for Green Economy; Routledge: London, UK, 1989.

2. UNEP. Towards a Green Economy: Pathways to Sustainable Development and Poverty Eradication. 2011. Available online: https://sustainabledevelopment.un.org/content/documents/126GER_synthesis_en.pdf (accessed on 15 July 2021).

3. Ryszawska, B. Zielona Gospodarka-Teoretyczne Podstawy Koncepcji i Pomiar jej Wdrażania w Unii Europejskiej (Green Economy-Theoretical Foundations of the Concept and Measurement of Its Implementation in the European Union); Wydawnictwo Uniwersytetu Ekonomicznego we Wrocławiu: Wrocław, Poland, 2013; pp. 48-60. (In Polish)

4. Ryszawska, B. Zielona Gospodarka w Dokumentach Strategicznych Unii Europejskiej (The Transition towards the Green Economy in European Union's Strategic Documents). Ekon. Śr. 2013, 3, 26-37. (In Polish)

5. Allen, C.; Clouth, S. A Guidebook to the Green Economy. Issue 1: Green Economy, Green Growth, and Low-Carbon Development-History, Definitions and $a$ Guide to Recent Publications; UN Division for Sustainable Development: New York, NY, USA, 2012. Available online: https://sustainabledevelopment.un.org/content/documents/GE\%20Guidebook.pdf (accessed on 18 July 2021).

6. Bina, O. The Green Economy and Sustainable Development: An Uneasy Balance? Environ. Plan. C Gov. Policy 2013, 31, 1023-1047. [CrossRef]

7. Georgeson, L.; Maslin, M.; Poessinouw, M. The Global Green Economy: A Review of Concepts, Definitions, Measurement Methodologies and their Interactions. Geogr. Environ. 2017, 4, e00036. [CrossRef]

8. Mealy, P.; Teytelboym, A. Economic Complexity and the Green Economy. Res. Policy 2020, 103948. [CrossRef]

9. Michalak, D.; Rosiek, K.; Szyja, P. Gospodarka Niskoemisyjna, Gospodarka Cyrkularna, Zielona Gospodarka. Uwarunkowania i Wzajemne Powiazania (Low-Carbon Economy, Circular Economy, Green Economy. Determinants and Interconnections); Wydawnictwo Uniwersytetu Łódzkiego: Łódź, Poland, 2020; ISBN 978-83-8220-032-4. (In Polish) [CrossRef]

10. Shafter, K. Challenges of the Green Economy: Review of Concepts and Definitions. Eur. J. Manag. Soc. Sci. 2020, 2, 95-100. [CrossRef]

11. Anser, M.K.; Usman, M.; Godil, D.I.; Shabbir, M.S.; Sharif, A.; Tabash, M.I.; Lopez, L.B. Does Globalization Affect the Green Economy and Environment? The Relationship between Energy Consumption, Carbon Dioxide Emissions, and Economic Growth. Environ. Sci. Pollut. Res. 2021. [CrossRef]

12. Limsuwan, K.; Thiengkamol, N.; Thiengkamol, C. Major Factors Affecting Green Economy Model. Ann. RSCB 2021, 25, 1074-1088.

13. Odugbesan, J.A.; Rjoub, H.; Ifediora, C.U.; Iloka, C.B. Do Financial Regulations Matters for Sustainable Green Economy: Evidence from Turkey. Environ. Sci. Pollut. Res. 2021. [CrossRef]

14. Licastro, A.; Sergi, B.S. Drivers and Barriers to a Green Economy. A Review of Selected Balkan Countries. Clean. Eng. Technol. 2021, 4, 100228. [CrossRef]

15. Wu, M.; Wu, J.; Zang, C. A Comprehensive Evaluation of the Eco-carrying Capacity and Green Economy in the Guangdong-Hong Kong-Macao Greater Bay Area, China. J. Clean. Prod. 2021, 281, 124945. [CrossRef]

16. UNDESA. A Guidebook to the Green Economy. Issue 3: Exploring Green Economy Policies and International Experience with National Strategies; UN Division for Sustainable Development: New York, NY, USA, 2012. Available online: http: / / sustainabledevelopment. un.org/content/documents/738GE\%20Publication.pdf (accessed on 18 July 2021).

17. Eaton, D.; Sheng, F. (Eds.) Inclusive Green Economy: Policies and Practice; Zayed International Foundation for the Environment \& Tongji University: Shanghai, China, 2019.

18. Khoshnava, S.M.; Rostami, R.; Zin, R.M.; Štreimikienè, D.; Yousefpour, A.; Strielkowski, W.; Mardani, A. Aligning the Criteria of Green Economy (GE) and Sustainable Development Goals (SDGs) to Implement Sustainable Development. Sustainability 2019, 11, 4615. [CrossRef]

19. Dogaru, L. Green Economy and Green Growth-Opportunities for Sustainable Development. Proceedings 2020, 63, 3070. [CrossRef]

20. Mikhno, I.; Koval, V.; Shvets, G.; Garmatiuk, O.; Tamošiūnienė, R. Green Economy in Sustainable Development and Improvement of Resource Efficiency. Cent. Eur. Bus. Rev. 2021, 10, 99-113. [CrossRef]

21. Green Growth, Green Profit: How Green Transformation Boosts Business; Roland Berger Strategy Consultants GmbH: Palgrave Macmillan, UK, 2011; ISBN 978-1349330560. Available online: https:/ / www.palgrave.com/gp/book/9780230285439 (accessed on 24 July 2021) [CrossRef]

22. UNDP. Green Economy in Action: Articles and Excerpts that Illustrate Green Economy and Sustainable Development Efforts; 38; United Nations Development Programme. 2012. Available online: https://www.un.org/waterforlifedecade/pdf/green_ economy_in_action_eng.pdf (accessed on 18 July 2021).

23. UNDESA. A Guidebook to the Green Economy. Issue 4: A Guide to International Green Economy Initiatives, Division for Sustainable Development; UN Division for Sustainable Development. 2013. Available online: http://sustainabledevelopment.un. org/ (accessed on 18 July 2021).

24. Bhuju, D.R.; Thapa-Parajuli, R.B.; Sharma, P.; Aryal, P. Nepal's Green Economy Initiative and Framework Proposed. Nep J. Environ. Sci. 2014, 2, 15-25. [CrossRef]

25. Denona Bogovic, N.; Grdic, Z.S. Transitioning to a Green Economy—Possible Effects on the Croatian Economy. Sustainability 2020, 12, 9342. [CrossRef] 
26. Vuola, M.; Korkeakoski, M.; Vähäkari, N.; Dwyer, M.B.; Hogarth, N.J.; Kaivo-oja, J.; Luukkanen, J.; Chea, E.; Thuon, T.; Phonhalath, K. What is a Green Economy? Review of National-Level Green Economy Policies in Cambodia and Lao PDR. Sustainability 2020, 12, 6664. [CrossRef]

27. Ali, E.B.; Pavlovich Anufriev, V.; Amfo, B. Green Economy Implementation in Ghana as a Road Map for a Sustainable Development Drive: A Review. Sci. Afr. 2021, 12, e00756. [CrossRef]

28. Steblyanskaya, A.; Ye, A.M.; Bocharnikov, V.; Denisov, A. Strategies for Green Economy in China. Foresight STI Gov. 2021, 15, 74-85. [CrossRef]

29. Górka, K.; Łuszczyk, M. Zielona Gospodarka i Gospodarka Oparta na Wiedzy a Rozwój Trwały. Optimum Studia Ekonomiczne 2014, 3, 22-31. [CrossRef]

30. Ferreira Gregorio, V.; Pié, L.; Terceño, A. A Systematic Literature Review of Bio, Green and Circular Economy Trends in Publications in the Field of Economics and Business Management. Sustainability 2018, 10, 4232. [CrossRef]

31. D'Amato, D.; JKorhonen, J. Integrating the Green Economy, Circular Economy and Bioeconomy in a Strategic Sustainability Framework. Ecol. Econ. 2021, 188, 107143. [CrossRef]

32. Chen, Y.; Chen, C.-Y.; Hsieh, T. Exploration of Sustainable Development by Applying Green Economy Indicators. Environ. Monit Assess 2011, 182, 279-289. [CrossRef] [PubMed]

33. EEA. Environmental Indicator Report 2012. Ecosystem Resilience and Resource Efficiency in a Green Economy in Europe; European Environment Agency: Copenhagen, Denmark, 2012.

34. EEA. Towards a Green Economy in Europe; European Environmental Agency: Copenhagen, Denmark, 2013.

35. UNEP. Measuring Progress Towards an Inclusive Green Economy; United Nations Environment Programme: Nairobi, Kenya, 2012. Available online: https://www.gwp.org/globalassets/global/toolbox/references/measuring-progress-towards-an-inclusivegreen-economy-unep-2012.pdf (accessed on 15 July 2021).

36. UNEP. Green Economy. A Guidence Manual for Green Economy Indicators; United Nations Environment Programme: Nairobi, Kenya, 2014. Available online: https://www.un-page.org/files/public/content-page/unep_indicators_ge_for_web.pdf (accessed on 19 July 2021).

37. Ryszawska, B. Green economy indicators. In Towards a Green Economy; Burchard-Dziubińska, M., Ed.; Wydawnictwo Uniwersytetu Łódzkiego: Łódź, Poland, 2015; Volume 2, pp. 31-52.

38. Green Economy: Indicators for Progress Measurement; Executive summary; Federal Department of the Environment; Federal Office for the Environment FOEN: Bern, Switzerland, 2016. Available online: https://www.bafu.admin.ch/dam/bafu/en/dokumente/ wirtschaft-konsum/fachinfo-daten/kurzfassung_gruenewirtschaftindikatorenzurmessungderforschritte.pdf.download.pdf/ executive_summarygreeneconomyindicatorsforprogressmeasurement.pdf (accessed on 19 July 2021).

39. PAGE. The Green Economy Progress Measurement Framework. Methodology; PAGE (United Nations): Chatelaine-Geneva, Switzerland, 2017. Available online: https:/ / www.un-page.org/files/public/gep_methodology.pdf (accessed on 19 July 2021).

40. PAGE. The Green Economy Progress Measurement Framework. Application; PAGE (United Nations): Chatelaine-Geneva, Switzerland, 2017. Available online: https://www.un-page.org/files/public/green_economy_progress_measurement_framework_ application.pdf (accessed on 19 July 2021).

41. Dual Citizen LLC. Performance Index 2018. Available online: https://dualcitizeninc.com/global-green-economy-index/ economic-environmental-indicators.php?id=3 (accessed on 19 July 2021).

42. Merino-Saum, A.; Baldi, M.G.; Gunderson, I.; Oberle, B. Articulating Natural Resources and Sustainable Development Goals through Green Economy Indicators: A Systematic Analysis. Resour. Conserv. Recycl. 2018, 139, 90-103. [CrossRef]

43. Vukovic, N.; Pobedinsky, V.; Mityagin, S.; Drozhzhin, A.; Mingaleva, Z. A Study on Green Economy Indicators and Modeling: Russian Context. Sustainability 2019, 11, 4629. [CrossRef]

44. Alekna, R.; Kazlauskiene, E. Evaluation Indicators of Green Economic Development: The Case of the Baltic Countries. Econ. Cult. 2020, 17, 150-163. [CrossRef]

45. Ul Mustafa, A.; Afzal, H.; Zahoor, Z. Green Economy and its Future. J. Sustain. Tour. Entrep. 2020, 2, 119-131. [CrossRef]

46. Cabernard, L.; Pfister, S. A Highly Resolved MRIO Database for Analyzing Environmental Footprints and Green Economy Progress. Sci. Total Environ. 2021, 755, 142587. [CrossRef]

47. Daniek, K. Green Economy Indicators as a Method of Monitoring Development in the Economic, Social and Environmental Dimensions. Soc. Inequal. Econ. Growth 2020, 2, 150-173. [CrossRef]

48. Balmford, A.; Bennun, L.; Ten Brink, B.; Cooper, D.; Côté, M.I.; Crane, P.; Dobson, A.; Dudley, N.; Dutton, I.; Green, R.E.; et al. The Convention on Biological Diversity's 2010 Target. Science 2005, 307, 212-213. [CrossRef]

49. Cornescu, V.; Adam, R. Considerations Regarding the Role of Indicators used in the Analysis and Assessment of Sustainable Development in the EU. Procedia Econ. Financ. 2014, 8, 10-16. [CrossRef]

50. Handbook on Constructing Composite Indicators. Methodology and User Guide; OECD Publishing: Paris, France, 2008. Available online: https: / / www.oecd.org/sdd/42495745.pdf (accessed on 24 July 2021).

51. Dziechciarz, J. Ekonometria. Metody, Przykłady, Zadania. (Econometrics. Methods, Examples, Tasks); Wydawnictwo Uniwersytetu Ekonomicznego: Wrocław, Poland, 2012; ISBN 978-83-7695-147-8. (In Polish)

52. Hellwig, Z. Zastosowanie metody taksonomicznej do typologicznego podziału krajów ze względu na poziom ich rozwoju oraz zasoby i strukture wykwalifikowanych kadr (The Application of the Taxonomic Method to the Typological Division of Countries by Level of their Development as Well as Resources and Structure of Qualified Staff). Prz. Stat. 1968, 4, 307-326. (In Polish) 
53. Hellwig, Z.S. Taksonometryczne Modele Zmian Struktury (Taxonomic Models of Structure Change); Instytut Rozwoju i Studiów Strategicznych: Warszawa, Poland, 1995. (In Polish)

54. Pluta, W. Wielowymiarowa Analiza Porównawcza w Badaniach Ekonomicznych. Metody Taksonomiczne i Analizy Czynnikowe (Multivariate Comparative Analysis in Economic Research. Taxonomic Methods and Factor Analysis); PWE: Warszawa, Poland, 1977.

55. Strahl, D. (Ed.) Metody Oceny Rozwoju Regionalnego (Methods for Evaluation of Regional Development); AE Publishing House: Wrocław, Poland, 2006. (In Polish)

56. Grzebyk, M.; Stec, M. Sustainable Development in EU Countries: Concept and Rating of Levels of Development. Sustain. Dev. 2015, 23, 110-123. [CrossRef]

57. Sulich, A.; Sołoducho-Pelc, L. Renewable Energy Producers' Strategies in the Visegrád Group Countries. Energies 2021, 14, 3048. [CrossRef]

58. Walesiak, M. Uogólniona Miara Odległości GDM w Statystycznej Analizie Wielowymiarowej w Wykorzystaniem Programu R (Generalized GDM Distance Measure in Statistical Multivariate Analysis Using R Software); Wydawnictwo Uniwersytetu Ekonomicznego: Wrocław, Poland, 2011. (In Polish)

59. Kasztelan, A. How Circular Are the European Economies? A Taxonomic Analysis Based on the INEC (Index of National Economies' Circularity). Sustainability 2020, 12, 7613. [CrossRef]

60. Kukuła, K. Metoda Unitaryzacji Zerowanej (The Zero Unitarization Method); Wydawnictwo Naukowe PWN: Warszawa, Poland, 2000. (In Polish)

61. Kijek, A. Sector Risk of the Processing Industry. In Modeling and Assessment (Ryzyko Sektorowe Przemystu Przetwórczego: Modelowanie i Ocena); UMCS Publishing House: Lublin, Poland, 2013.

62. Fura, B.; Stec, M.; Miś, T. Statistical Evaluation of the Level of Development of Circular Economy in European Union Member Countries. Energies 2020, 13, 6401. [CrossRef]

63. Jarocka, M. Wybór Formuły Normalizacyjnej w Analizie Porównawczej Obiektów Wielocechowych (The Choice of a Formula of the Data Normalization in the Comparative Analysis of Multivariate Objects). Econ. Manag. 2015, 1, 113-126. (In Polish)

64. Kasztelan, A.; Nowak, A. Construction and Empirical Verification of the Agri-Environmental Index (AEI) as a Tool for Assessing the Green Performance of Agriculture. Energies 2021, 14, 45. [CrossRef]

65. Dual Citizen, L.L.C. 2018 Global Green Economy Index (GGEI); Dual Citizen L.L.C: New York, NY, USA, 2018. Available online: https:/ / dualcitizeninc.com/global-green-economy-index/ (accessed on 24 July 2021). 